\title{
DESAIN PEMBELAJARAN PERBANDINGAN SENILAI MENGGUNAKAN GUIDED INQUIRY
}

\author{
Danty Rahmasantika, Rully Charitas Indra Prahmana \\ Universitas Ahmad Dahlan, Jl. Ringroad Selatan, Bantul, Yogyakarta 55161, Indonesia \\ Email: rully.indra@mpmat.uad.ac.id
}

\begin{abstract}
Abstrak
Penelitian ini bertujuan untuk mendukung pemahaman siswa dalam pembelajaran materi perbandingan dan mengetahui hasil belajar siswa dalam pembelajaran perbandigan senilai melalui LAS berbasis model pembelajaran guided inquiry. Penelitian ini menggunakan metode penelitian design research, yang dilaksanakan di kelas VII B SMP N 1 Berbah Sleman. Instrumen penelitian yang digunakan adalah alat perekam, lembar tes tertulis, lembar catatan lapangan, dan lembar daftar pertanyaan. Hasil penelitian menunjukkan bahwa pada pertemuan ke-1 dan ke-2 siswa terlihat masih beradaptasi dengan desain pembelajaran yang diterapkan. Pada pertemuan selanjutnya, siswa dapat mengikuti kegiatan pembelajaran dengan lebih baik. Selain itu, hasil belajar siswa menunjukkan bahwa nilai rata-rata yang diperoleh siswa adalah 71,57 dengan Kriteria Ketuntasan Minimum (KKM) untuk perbandingan senilai sebesar 70.
\end{abstract}

Kata kunci: Design Research, Desain Pembelajaran Perbandingan Senilai, Guided Inquiry.

\begin{abstract}
This study aims to support students' understanding of learning comparative material and determine student learning outcomes incomparable learning through LAS-based guided inquiry learning models. This study uses a research design research method, which was carried out in class VII B SMP N 1 Berbah Sleman. The research instruments used were recording devices, written test sheets, field notes sheets, and questionnaire sheets. The results showed that at the 1 st and 2nd meetings, students were seen to be still adapting to the learning design applied. At the next meeting, students can participate in learning activities better. Also, student learning outcomes indicate that the average value obtained by students is 71.57 with Minimum Completeness Criteria (KKM) for a comparison of 70.
\end{abstract}

Keywords: Design Research, Value Comparative Learning Design, Guided Inquiry.

\section{PENDAHULUAN}

Dole, dkk (2009) menyatakan bahwa dampak dari kurangnya pemahaman konsep dan rendahnya penalaran matematis menyebabkan siswa mengalami kesulitan dalam mengerjakan tugas perbandingan yang berbentuk soal cerita; siswa hanya mampu melakukan perhitungan perbandingan tanpa mengetahui konsep dari perhitungan 
tersebut. Disisi lain, perbandingan merupakan salah satu materi matematika yang diajarkan pada Sekolah Menengah Pertama (SMP) kelas VII di Indonesia (Permendikbud Nomor 24, 2016). Oleh sebab itu, perbandingan tergolong materi yang sulit bagi siswa, dikarenakan kurangnya pemahaman konsep siswa terhadap materi perbandingan.

Hasil penelitian menunjukkan bahwa guru hanya menjelaskan apa itu perbandingan saja, bukan memberikan pemahaman materi ajar secara jelas dan bermakna bagi siswa sehingga ketika diberikan sebuah permasalahan siswa dapat menjawab dengan benar namun siswa tidak mampu membuktikan proses menuju jawaban yang benar tersebut yang membuktikan bahwa siswa tidak benar-benar paham dengan apa yang dikerjakannya (Pakarti, dkk, 2016). Selanjutnya, informasi dari hasil wawancara dengan guru SDN 117 Palembang dengan materi bilangan tentang perbandingan dan skala diperoleh bahwa ketika siswa diminta untuk mengerjakan latihan soal, mereka tidak bisa mengerjakannya dikarenakan latihan soal berbeda dengan soal yang dicontohkan oleh guru, dalam hal ini guru masih tergantung pada buku ajar sebagai media pembelajaran (Diba, dkk. 2009). Sehingga, kesulitan siswa terhadap materi perbandingan disebabkan oleh kurangnya peranan guru sebagai fasilitator bagi siswa dan minimnya kemampuan siswa dalam pemahaman konsep pada materi perbandingan.

Di lain pihak, diketahui bahwa karakteristik kurikulum 2013 adalah mengembangkan sikap, pengetahuan dan keterampilan siswa (Machali, 2014). Sejalan dengan itu, guided inquiry merupakan salah satu metode yang cocok untuk digunakan pada kurikulum 2013 dengan menggunakan bahan ajar yang baik dan menarik dapat membangun pengetahuan siswa (Novitasari, dkk. 2016). Sehingga, metode guided inquiry cocok untuk diterapkan pada pembelajaran di kelas dengan menggunakan kurikulum 2013.

Afandi dan Wustqa (2013) menyatakan bahwa dengan melalui metode pembelajaran guided inquiry, siswa dapat menganalisa suatu masalah dan mampu menarik kesimpulan dari masalah tersebut. Selanjutya, hasil penelitian yang dilakukan Prayitno dan Wulandari (2015) menunjukkan bahwa metode pembelajaran guided inquiry meminimalkan kesalahan pecahan yang merupakan materi prasyarat perbandingan. Selanjutnya, terdapat 3 tahapan aktifitas dalam mengenalkan konsep 
perbandingan yaitu mengukur dan menentukan sisi-sisi yang bersesuaian, menentukan hubungan diantara dua rasio, siswa dapat menyimpulkan kedua rasio senilai atau bukan dengan cara mengali atau membagi dengan bilangan yang sama, dan memberikan permasalahan perbandingan senilai yang berhubungan dengan kehidupan nyata (Rahmawati \& Susanti, 2016). Oleh sebab itu, peneliti mencoba mengadopsi 3 tahapan aktifitas dalam mengenalkan konsep perbandingan tersebut menggunakan metode pembelajaran guided inquiry.

Haeruman, dkk. (2017) menyatakan bahwa guru sering menerapkan metode ekspositori dalam pembelajarannya, yaitu proses penyampaian materi dari guru kepada kelompok siswa dengan tujuan agar siswa mampu menguasai materi dengan optimal”. Namun, pada realitanya hal itu hanya terjadi pada awal pembelajaran saja, selebihnya para siswa kerap kali mengobrol sendiri dengan temannya, bermain sendiri, dan sibuk sendiri dengan kegiatannya tanpa memperhatikan guru (Febrian, dkk. 2013). Sehingga, metode ekspositori dinilai kurang menarik bagi siswa untuk lebih memperhatikan guru pada saat proses pembelajaran di kelas.

Hasil penelitian yang dilakukan Rahmasantika dan Prahmana (2018) di SMP N 1 Berbah menunjukkan bahwa siswa dengan kategori kecerdasan rendah belum mampu menerapkan konsep pecahan dalam bentuk soal cerita, sedangkan siswa dengan kategori kecerdasan sedang belum mampu menentukan nilai pecahan dengan tuntas. Pecahan merupakan salah satu materi prasyarat untuk materi perbandingan. Sedangkan, kesalahan siswa dalam menyelesaikan suatu permasalahan perbandingan adalah mengabaikan hubungan antar bilangan yang menyusun perbandingan tersebut (Raharjanti, dkk. 2016). Berdasarkan uraian di atas, peneliti tertarik untuk mendesain pembelajaran materi perbandingan untuk siswa kelas VII dengan menggunakan metode guided inquiry.

\section{METODE PENELITIAN}

Penelitian ini menggunakan metode penelitian Desain Riset (design research). Design Research merupakan metode penelitian dimana peneliti melakukan serangkaian pendekatan yang bertujuan untuk menghasilkan teori, artefak atau serangkaian praktik baru yang dapat mempengaruhi proses pembelajaran secara alami (Ploom, 2013, Tanujaya, dkk. 2018). Prosedur pelaksanaan penelitian pada design research meliputi 3 
(tiga) langkah utama, yaitu: preparing for the experiment/preparation and design phase (Bakker, 2004), design experiment, dan restrospective analysis (Gravemeijer \& Coob, 2006).

Penelitian ini dilakukan di SMP Negeri 1 Berbah Sleman Yogyakarta. Penelitian ini telah dilakukan pada semester genap tahun akademik 2018/2019. Subjek penelitian ini adalah seluruh siswa pada salah satu kelas VII SMP N 1 Berbah Sleman Yogyakarta. Objek pada penelitian ini adalah pengenalan konsep perbandingan senilai.

Teknik pengumpulan data yang digunakan dalam penelitian ini adalah dokumentasi, data tertulis, observasi, dan wawancara (Prahmana, 2017). Selanjutnya, instrumen yang digunakan dalam penelitian yaitu alat perekam, lembar tes tertulis siswa, lembar catatan lapangan, dan lembar daftar pertanyaan. Data yang diperoleh pada penelitian di analisis dengan cara analisis data, validitas, dan reliabilitas (Prahmana, 2017). Indikator kelayakan dengan metode guided inquiry diperoleh melalui hasil belajar peserta didik terhadap pembelajaran perbandingan senilai. Kriteria Ketuntasan Minimum (KKM) untuk pembelajaran perbandingan senilai di SMP N 1 Berbah Sleman adalah 70 .

\section{HASIL DAN PEMBAHASAN}

Penelitian ini dilaksanakan sebanyak 4 kali pertemuan. Pada pertemuan 1 sampai dengan 3 diberikan Lembar Aktivitas Siswa, selanjutnya pada pertemuan terakhir diadakan evaluation test. Untuk lebih jelasnya dapat dilihat pada Tabel 1.

Tabel 1. Jadwal Pelaksanaan Kegiatan Pembelajaran

\begin{tabular}{|c|c|c|c|c|}
\hline Pertemuan & $\begin{array}{c}\text { Kegiatan } \\
\text { Siswa }\end{array}$ & $\begin{array}{c}\text { Hari, } \\
\text { Tanggal }\end{array}$ & Materi & Capaian Aktivitas \\
\hline $\mathbf{I}$ & LAS 1 & $\begin{array}{l}\text { Selasa, } \quad 8 \\
\text { Januari } \\
2019\end{array}$ & $\begin{array}{l}\text { Perbandingan } \\
\text { Dua Besaran } \\
\& \\
\text { Perbandingan } \\
\text { Senilai }\end{array}$ & $\begin{array}{l}\text { 1. Siswa mampu menemukan } \\
\text { sisi-sisi yang bersesuaian } \\
\text { 2. Siswa mampu menuliskan } \\
\text { rasio dalam berbagai } \\
\text { bentuk } \\
\text { 3. Siswa mampu menyelidiki } \\
\text { perbandingan senilai yang } \\
\text { dilihat dari hasil } \\
\text { pengukuran kertas }\end{array}$ \\
\hline II & LAS 2 & $\begin{array}{l}\text { Selasa, } 22 \\
\text { Januari } \\
2019\end{array}$ & $\begin{array}{l}\text { Perbandingan } \\
\text { dua besaran } \\
\text { satuannya }\end{array}$ & $\begin{array}{l}\text { 1. Siswa mampu menghitung } \\
\text { rasio dalam berbagai } \\
\text { bentuk }\end{array}$ \\
\hline
\end{tabular}


sama berbeda

$\begin{array}{ll}\text { Kamis, 24 } & \text { Masalah } \\ \text { Januari } & \text { yang Terkait } \\ 2019 & \text { Dengan } \\ & \text { Perbandingan } \\ & \text { Senilai }\end{array}$

III LAS 3

IV dan 2. Siswa mampu melakukan perhitungan nilai $x$ berdasarkan model matematika

3. Siswa mampu menghitung nilai yang ditanyakan dari permasalahan kontekstual

1. Siswa mampu membuat tabel dan menyelesaikan permasalahan perbandingan senilai

2. Siswa mampu membuat grafik dan menyelesaikan permasalahan perbandingan senilai

3. Siswa mampu membuat persamaan dan menyelesaikan permasalahan perbandingan senilai

1. Siswa mampu menyelesaiakan evaluation test dengan benar

Pembelajaran perbandingan senilai dilakukan di kelas VII B dengan menggunakan instrumen tes tertulis yang telah divalidasi sebelumnya. Pada materi perbandingan dua besaran \& perbandingan senilai kegiatan pembelajaran dilaksanakan dengan menggunakan bantuan alat peraga yaitu meteran jahit. Dari pembelajaran, didapatkan hasil observasi kegiatan pembelajaran perbandingan senilai berupa catatan lapangan dan analisis data tes tertulis. Berikut ini adalah penjabaran kegiatan guru, kegiatan siswa dan hasil data tes tertulis dalam pembelajaran perbandingan senilai yang telah dilakukan oleh peneliti.

\section{Deskripsi dan Analisis Kegiatan Pembelajaran Perbandingan Senilai}

\section{$\underline{\text { Pertemuan I }}$}

Pada awal pembelajaran guru menyapa siswa kemudian mengecek kehadiran siswa. Selanjutnya, guru menginformasikan bahwa materi pembelajaran hari ini adalah perbandingan. Kemudian, guru memulai kegiatan pembelajaran dengan memberikan arahan kepada siswa untuk berdiskusi menggunakan Lembar Aktivitas Siswa (LAS). Siswa terlihat bersemangat melakukan pengukuran panjang dan lebar menggunakan 
meteran jahit. Sedangkan, guru ikut memantau dan memerhatikan pengukuran yang dilakukan siswa. Pada saat siswa mengerjakan aktivitas 1 LAS dan mengukur bendabenda yang ada di sekitarnya, guru berkeliling kelas untuk mengecek pekerjaan dan memberikan bantuan kepada siswa yang mengalami kesulitan. Salah satu kasus kesulitan yang didapatkan yaitu siswa masih tampak kebingungan dalam menemukan sisi-sisi yang bersesuaian yang terlihat ketika guru menanyakan kesimpulannya. Untuk lebih jelasnya terlihat pada Dialog 1.

\section{Dialog 1}

Guru : Nah dari hasil pengukuran kamu itu. Kamu lihat. Apakah sisi-sisi yang bersesuaian itu antara kedua pengukuran tersebut yaitu dari pengukuran pertama dan pengukuran kedua itu bersesuaian apa nggak gitu lho? Panjang pengukuran pertama dengan panjang pengukuran kedua apakah sama dengan lebar pertama dengan lebar yang kedua? Sama nggak?

Siswa : ...... (Tampak bingung dan tidak menjawab apapun)

Guru : Sama nggak? (Mengulangi pertanyaannya)

Siswa : Tidak.

Guru : Tidak. Lebih. Lebih apa?

Siswa : Lebih lurus. (Jawab siswa dengan keraguan)

Guru : Lebih panjang. Iya kan? Dari pada yang kedua. Jadi apa itu jawabannya?

Siswa : ...... (Tampak bingung dan tidak menjawab kembali)

Guru : Jadi sisi-sisi yang bersesuaian dari pengukuran pertama dan pengukuran kedua adalah ....

Siswa 1 : Tidak sebanding.

Guru : Tidak sebanding?

Siswa 1 : Iya.

Guru : Iya. Tidak sebanding. (Mengulang jawaban yang diucapkan siswa).

Berbeda dari aktivitas sebelumnya, pada aktivitas 2 siswa diberikan suatu permasalahan mengenai perbandingan senilai. Kemudian diberikan beberapa kertas untuk diukur siswa secara berkelompok dengan teman sebangkunya. Siswa diminta melakukan pengukuran dari beberapa kertas yang diberikan untuk dapat menemukan rasio dari data hasil pengukuran tersebut. Siswa sudah bisa mengikuti aktivitas 2 dengan baik terlihat berdasarkan kesimpulan yang diberikan oleh siswa bahwa siswa dapat menyelidiki perbandingan senilai melalui hasil rasio yang telah dihitung.

Kemudian, guru mengarahkan kepada siswa untuk mengerjakan aktivitas 3 dalam LAS. Pada aktivitas ini, siswa diminta untuk mengukur tinggi badan siswa, bayangan siswa, dan bayangan tiang gawang menggunakan alat peraga meteran jahit. Sesekali guru mengingatkan siswa agar mencatat hasil data pengukuran di LAS mereka, karena terdapat beberapa siswa yang lupa mencatatnya sehingga membuat siswa melakukan 
pengukuran ulang. Siswa melanjutkan berdiskusi di dalam ruang kelas dengan teman di samping atau depan belakangnya untuk menyelesaikan permasalahan aktivitas 3 .

Kemudian, kegiatan selanjutnya adalah guru menawarkan kepada siswa untuk menuliskan hasil data pengukuran di papan tulis. Ada 2 orang siswa laki-laki dan 1 orang siswa perempuan yang menuliskan hasil data pengukurannya. Kemudian guru menawarkan kepada siswa untuk bertanya, namun tidak ada pertanyaan yang diajukan kepada guru. Kegiatan selanjutnya yaitu, guru mengevaluasi dan mereview kembali materi pembelajaran yang telah dipelajari. Dengan adanya evaluasi, guru dapat mengetahui sejauh mana tingkat pemahaman, penguasaan materi, dan kesulitan belajar pada siswa (Untari, 2013). Kemudian guru menginformasikan materi yang akan dipelajari untuk pertemuan selanjutnya dan menyarankan siswa untuk mempelajarinya terlebih dahulu di rumah.

\section{Pertemuan II}

Pada awal kegiatan pembelajaran, guru menginformasikan kepada siswa bahwa pembelajaran hari ini adalah perbandingan senilai, melanjutkan dari materi pada pertemuan sebelumnya. Kemudian, guru membagikan Lembar Aktivitas Siswa dan memerintahkan siswa untuk memahami aktivitas-aktivitas pada LAS.

Selanjutnya sesuai dengan arahan guru, siswa berdiskusi dengan teman sebangkunya, sedangkan guru berkeliling kelas untuk melihat hasil pekerjaan siswa dan membimbing siswa yang mengalami kesulitan. Guru juga mengingatkan agar semua siswa mencoba mengerjakan aktivitas-aktivitas LAS, tidak boleh hanya diam saja dan biasakan untuk berpikir dalam mengerjakan soal-soal yang disediakan. Karena seringkali siswa hanya mengikuti hasil pekerjaan temannya. Kesulitan-kesulitan yang dialami siswa diantaranya adalah siswa bingung menentukan langkah awal dalam pengerjaan aktivitas 2 LAS. Untuk lebih jelasnya terlihat pada Dialog 2.

\section{Dialog 2}

Guru : Pertanyaannya apa? Pertanyaan yang b? 10 kali putaran berapa waktunya gitu kan? Ini pertama kali putaran, putaran yang pertama kali berapa jadi? 4 kali tho? (Guru mendatangi salah satu siswa)

Siswa 3 : (Siswa mengangguk)

Guru : 4 kali. Berapa 4 kali si Reza (waktunya)?

Siswa 3 : 8 menit.

Guru : 8 menit. Putaran pertama per ini (waktu yang dbutuhkan pertama kali). Putaran kedua per? Tidak tahu. Begitu tho?

Siswa 3 : (Siswa sambil mengerjakan aktivitas 2 LAS) 
Guru : Okey. Bukan. Ini kan ini berapa? 4 putaran tadi si Reza berapa itu? (Guru melihat pekerjaan siswa 1 namun keliru, kemudian guru bertanya ke seluruh siswa)

Siswa : 8 menit (Jawab seluruh siswa)

Guru : Kan atasnya tulisannya apa itu?

Siswa : Banyaknya putaran pertama kali? (Jawab seluruh siswa lagi)

Guru : Iya. Banyaknya putaran banding waktu, gitu kan? Waktunya berapa?

Siswa : Iya. 4 (Jawab 2 orang siswa yang kurang teliti)

Guru : 8. Putarannya yang 4.

Siswa 4 : Walah..

Guru : Putarannya yang 4. Terus putaran kedua berapa kali?

Siswa : 10. (Jawab siswa bersamaan)

Guru : 10. Berapa kali dia memutar (waktunya)? Belum tahu. Ya tho? Nah, itu yang ditanyakan, gitu tho maksudnya?

Siswa 5: (Siswa mengangguk)

Kemudian dilanjutkan dengan aktivitas 3, guru membimbing siswa dalam mengerjakan soal cerita mengenai masalah kontekstual dari uang yang diterima Bunga. Guru meyakinkan siswa dengan bertanya bisa atau tidak dalam mengerjakannya. Siswa menjawab dengan spontan hasil perhitungannya, namun hasil perhitungan yang diutarakan siswa kurang tepat. Untuk lebih jelasnya terlihat pada Dialog 3.

\section{Dialog 3}

Guru : Menentukan uang kiriman yang diterima Bunga per hari pada bulan Januari hingga Maret yaitu...

Siswa 6 : Dibagi

Guru : Iya, dibagi. Tadi berapa 90 hari?

Siswa : 6 juta (Jawab seluruh siswa bersamaan)

Guru : Berarti seharinya kan? Tau tho? Bisa tho ngitung 6 juta dibagi 90 ketemunya?

Siswa 7 : Tujuh empat, empat ratus $(\operatorname{Rp} 74.400,00)$

Menurut perhitungan dan kunci jawaban yang sudah dibuat peneliti, hasil yang diutarakan siswa 7 keliru. Hasil sebenarnya adalah Rp 66.666,67. Jika dibandingan dengan hasil perhitungan siswa, perbedaannya cukup jauh. Sehingga dapat disimpulkan bahwa siswa kurang teliti dalam melakukan perhitungan aktivitas 3 ini.

Kegiatan selanjutnya adalah guru menawarkan kepada siswa untuk menuliskan hasil jawaban di papan tulis. Semua siswa memiliki jawaban yang sama, sehingga tidak ada siswa yang memberikan pendapat berbeda. Kemudian guru mengajak siswa untuk memberikan applause kepada siswa yang telah menuliskan hasil diskusinya. Selanjutnya, guru mereview kembali materi pembelajaran yang telah dipelajari 
mengenai perbandingan dua besaran satuannya sama dan berbeda.

\section{$\underline{\text { Pertemuan III }}$}

Pada awal kegiatan pembelajaran, guru memerintahkan siswa untuk membaca dengan teliti perintah dari aktivitas-aktivitas pada LAS. Selanjutnya, guru berkeliling kelas untuk melihat hasil pekerjaan siswa dan membimbing siswa yang mengalami kesulitan. Kesulitan yang dialami siswa pada pertemuan ini adalah siswa sulit memahami dan belum dapat membuat grafik pada permasalahan perbandingan senilai. Untuk lebih jelasnya terlihat pada Dialog 4.

\section{Dialog 4}

Guru : Ayo diisi noktah pertemuan antara banyaknya teman dengan banyaknya rambutan contohnya yaa ini. 0 terus kalo 1 apa? (Guru mendatangi siswa 3)

Siswa $3: 2$

Guru : 2. Terus apa? Jangan gitu, pilih 1 atau 2 (Sambil menunjuk LAS)

Siswa $3: 1$.

Guru : 2 nya mana?

Siswa 3 : Berarti sini (Sambil menunjuk LAS)

Guru : Iya, terus?

Siswa 3 : (Menunjuk LAS)

Guru : Salaah.

Siswa 13: Lha noktah e gitu tho buk?

[Lho, noktahnya begitu ya bu?]

Guru : Noktahnya dulu kamu buat, titik-titik antara pertemuan banyaknya teman dengan banyaknya rambutan. Temannya berapa?

Siswa $3: 1$

Guru : Iya, rambutannya 2. Temennya berapa?

Siswa $3: 2$

Guru : 2, rambutannya 4. Temennya berapa? 3, rambutannya 6. Dikasih noktahnoktahnya terus dihubungkan, ya tho?

Siswa 13: Dikasih noktah-noktahnya. (Mengingatkan teman sebangkunya)

Siswa 3 : Oh gituuu..

Guru membimbing siswa dengan sabar dalam membuat grafik pada permasalahan perbandingan senilai. Awalnya, guru hanya membimbing 2 orang siswa perempuan yang duduknya sebangku saja. Namun, siswa lainnya yang duduk di bangku depan dan belakang juga tertarik mendengarkan penjelasan bimbingan guru dalam membuat grafik. Kegiatan selanjutnya adalah guru menunjuk siswa 15 untuk menyampaikan hasil diskusi pada aktivitas membuat persamaan dan menyelesaikan permasalahan perbandingan senilai secara lisan. Kemudian guru menawarkan kepada semua siswa 
untuk menanyakan hasil diskusi, dikarenakan semua siswa memiliki jawaban yang sama, sehingga tidak ada pertanyaan untuk siswa 15 . Selanjutnya, siswa memberikan applause kepada siswa 15 .

Pertemuan IV

Pada awal pertemuan ini, guru menginformasikan kepada siswa bahwa akan dibagikan soal evaluasi. Siswa harus menyelesaikannya dalam waktu 2 jam pelajaran atau 80 menit. Soal evaluasi terdiri dari 5 soal. Proses siswa mengerjakan soal evaluasi berlangsung dengan lancar. Sesekali siswa bertanya kepada guru mengenai pertanyaan pada lembar soal dan guru menjelaskan bahwa ini adalah soal evaluasi sehingga harus dikerjakan secara individu berdasarkan hasil pemikirannya sendiri. Setelah semua sudah selesai mengerjakan, soal evaluasi pun dikumpulkan ke peneliti untuk dianalisis.

\section{Deskripsi dan Analisis Data Tes Tertulis}

Data tes tertulis digunakan untuk mengetahui kemampuan siswa pada materi konsep perbandingan senilai. Tes tertulis dilaksanakan pada pertemuan terakhir (evaluation test). Evaluation test dilaksanakan untuk mengetahui kemampuan siswa setelah diberikan treatment. Hasil tes tertulis evaluation test nomor 1 terdapat 12 siswa yang nilainya sempurna, sedangkan 18 siswa yang lainnya belum benar. Selanjutnya peneliti mengelompokkan kesalahan siswa menjadi 2 tipe kesalahan. Tipe kesalahan yang pertama dari siswa yang bernama Lisa. Lisa keliru dalam membagi data perbandingan. Tipe kesalahan yang kedua adalah siswa belum bisa membaca soal dengan benar atau belum bisa memahami maksud dari pertanyaan dengan benar. Siswa yang melakukan kesalahan ini adalah Gustiyan, Aisyah, Ikhsanna, Dyah, dan Ahmad.

Selanjutnya, hasil tes tertulis nomer 2 juga dikelompokkan menjadi 3 tipe kesalahan. Tipe kesalahan pertama adalah siswa tidak menuliskan model matematika pada lembar tes tertulis. Salah satu siswa yang mengalaminya adalah Ahmad. Kemudian, tipe kesalahan yang kedua adalah siswa yang bernama Septiana. Septiana keliru dalam proses perhitungannya. Dalam hal ini terdapat 7 siswa yang memiliki tipe kesalahan yang sama. Selanjutnya adalah tipe kesalahan ketiga, siswa tidak menyatakan satuan pada hasil akhir tes tertulisnya.

Tes tertulis selanjutnya, terdapat 9 siswa yang melakukan kesalahan pada soal nomer 3. Peneliti mengelompokkannya menjadi 2 tipe kesalahan. Tipe kesalahan nomer 
3 yang pertama adalah siswa yang bernama Rifky. Rifky tidak mengubah satuan waktu menjadi satuan yang sama, sehingga ketika dalam proses perhitungan tidak mendapatkan hasil akhir yang diharapkan. Layn dan Kahar (2017) menjelaskan bahwa dalam analisis kesalahan Newman, kendala siswa dalam pengolahan masalah matematika terdiri dari treansformasi, ketrampilan proses dan penulisan jawaban. Selain Rifky, siswa yang mengalami kesalahan tipe ini yaitu Wildhan, Salsha, Ahmad, dan Devi. Untuk lebih jelasnya dapat dilihat tes tertulis Rifky pada Gambar 1.

3. Sebuah mesin di suatu pabrik minuman mampu memasang tutup botol untuk 14 botol dalam waktu 84 detik. Banyak botol yang dapat ditutup oleh mesin dalam waktu 2 menit adalah ...

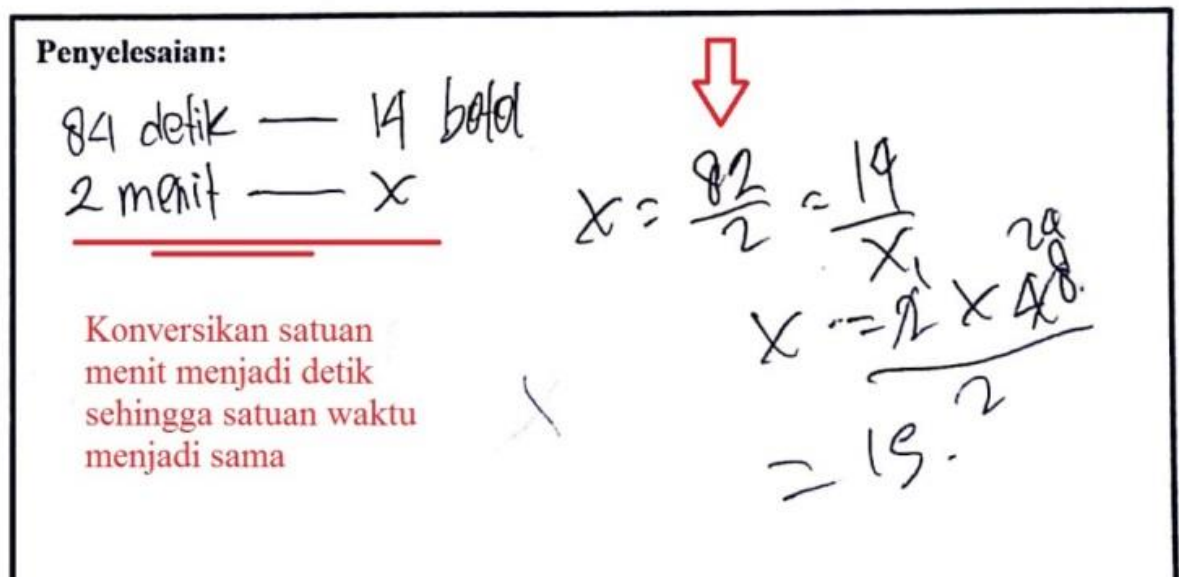

Gambar 1. Jawaban Tes Tertulis Rifky Nomor 3

Pada Gambar 1, Rifky sudah benar dalam menghubungkan 84 detik mampu memasang 14 tutup botol dan dalam 2 menit mampu memasang $x$ tutup botol. Tetapi, kesalahan fatal yang dilakukan Rifky adalah tidak mengonversikan atau mengubah satuan menit menjadi satuan detik agar satuan menjadi sama. Atau bisa juga diubah menjadi satuan menit. Ketika 2 menit dikonversikan menjadi satu satuan detik, maka akan menjadi 120 detik. Sedangkan, jika diubah menjadi satu satuan menit, maka 84 detik menjadi 1,4 menit. Kemudian, dibuatlah perbandingan senilai dari permasalahan ini. Namun, selain Rifky tidak mengonversikan besaran satuan, Rifky juga keliru dalam menuliskan 82 seperti pada tanda panah diatas. Seharusnya Rifky menuliskan 84 untuk menunjukkan 84 detik. Kesalahan yang diangkat dalam tipe kesalahan ini yaitu tidak mengonversikan besaran satuan menjadi sama.

Tipe kesalahan nomer 3 yang kedua adalah siswa tidak mengaitkan data yang ada 
menjadi model matematika perbandingan senilai. Pada tipe kesalahan ini, siswa yang mengalami kesalahan adalah Lisa, Gustiyan, Disti, dan Sheilla. Sheilla tidak mengumpulkan data yang terkait dengan permasalahan menjadi suatu model matematika yang berakibat pada perhitungan Sheilla $x=\frac{14 \times 84}{120}$ menjadi keliru, hal ini tentu saja salah dalam proses perhitungan dan cara berpikir Sheilla dalam menganalisis permasalahan perbandingan senilai.

Kemudian tes tertulis soal nomer 4, terdapat 14 siswa yang mendekati poin sempurna. Salah satu siswa yang termasuk didalamnya adalah Wildhan. Wildhan memiliki 2 tipe kesalahan dalam menyelesaikan permasalahan soal nomer 4 . Wildhan salah dalam proses perhitungan mencari nilai $x$, dimana $x$ merupakan panjang kamar untuk dihuni satu siswa. Kesalahan ini merupakan tipe kesalahan pertama dari hasil tes tertulis Wildhan. Kemudian, kesalahan kedua yang dilakukan oleh Wildhan adalah menafsirkan tipe ruang kamar 1 lebih luas dari pada tipe ruang kamar 2 untuk seorang siswa hanya melalui gambar. Hal ini menunjukkan bahwa proses berpikir Wildhan cenderung tidak memerhatikan perhitungannya, hanya berdasarkan apa yang dilihat. Kesalahan tipe ini membuat hasil akhir salah dan tidak sesuai dengan analisa perhitungan siswa.

Hasil evaluasi soal nomor 5 menunjukkan bahwa sebanyak 18 siswa dari 30 siswa masih kurang tepat dalam menyelesaikan soal tersebut. Kesalahan yang dialami siswa adalah siswa kurang dalam menyederhanakan perbandingan senilai, maka hasil akhir yang diperoleh siswa tidak sesuai seperti yang diharapkan peneliti. Kemudian siswa tidak menjawab secara keseluruhan butir-butir soal nomer 5 sehingga poin yang diperoleh tidak maksimal. Selain itu, persepsi siswa juga keliru dalam menjumlahkan komponen-komponen resep kue coklat. Kesalahan ini dialami oleh 3 orang siswa yaitu Bima, Naufal, dan Ashari.

Berdasarkan hasil evaluasi tes tertulis, terdapat 2 siswa yang memperoleh nilai tertinggi yaitu 93. Kedua siswa ini bernama Novaldo dan Arif. Kemudian siswa yang memperoleh nilai terendah adalah Gustiyan dengan nilai 28. Kriteria Ketuntasan Minimum (KKM) SMP Negeri 1 Berbah Sleman Yogyakarta untuk mata pelajaran Matematika kelas VII adalah 70. Nilai evaluation test siswa kelas VIIB SMP Negeri 1 Berbah Sleman Yogyakarta ditunjukkan pada Tabel 2.

Tabel 2 menunjukkan bahwa siswa yang tuntas pada saat evaluation test sebanyak 
18 siswa dan persentasenya $60 \%$, sedangkan sisanya tidak tuntas sebanyak 12 siswa dan persentasenya $40 \%$. Kegiatan evaluation test diikuti oleh 30 siswa pada pertemuan terakhir. Rata-rata nilai evaluation test siswa adalah 71,57.

Tabel 2. Kategori Nilai Evaluation Test Siswa

\begin{tabular}{cccc}
\hline Kategori & Nilai & Frekuensi & Persentase \\
\hline Tuntas & $\geq 70$ & 18 & $60 \%$ \\
Tidak tuntas & $<70$ & 12 & $40 \%$ \\
\hline
\end{tabular}

Pada pertemuan pertama, guru menginformasikan bahwa materi pembelajaran yang dipelajari adalah perbandingan. Pada saat siswa mengerjakan LAS 1 dan mengukur benda-benda yang ada di sekitarnya, guru berkeliling kelas untuk mengecek pekerjaan dan memberikan bantuan kepada siswa yang mengalami kesulitan. Salah satu kasus kesulitan yang didapatkan yaitu siswa masih tampak kebingungan dalam menemukan sisi-sisi yang bersesuaian yang terlihat ketika guru menanyakan kesimpulannya.

Pada pertemuan kedua, seperti pada pertemuan sebelumnya sesuai dengan arahan guru, siswa berdiskusi dengan teman sebangkunya, sedangkan guru berkeliling kelas untuk melihat hasil pekerjaan siswa dan membimbing siswa yang mengalami kesulitan. Sesekali, guru juga memberi arahan dalam mencari nilai rasio dengan menggunakan Faktor Persekutuan Terbesar (FPB) pada pembilang dan penyebut dari sebuah pecahan atau pada kedua bilangan yang diketahui, kemudian dibagi dengan bilangan yang sama hingga kedua bilangan menjadi sederhana dan tidak bisa dibagi lagi. Hal ini sejalan dengan Murpratiwi, dkk (2019: 1) mengatakan bahwa untuk menyederhanakan sebuah pecahan dapat menggunakan FPB.

Dilanjutkan dengan mengerjakan aktivitas 2 LAS, guru berkeliling kelas dan membimbing siswa yang mengalami kesulitan. Berdasarkan Dialog 2, guru membimbing siswa hingga siswa memahami bagaimana cara mengerjakannya. Tindakan bimbingan yang dilakukan oleh guru memberikan secara langsung konsep dan jawaban perbandingan senilai. Hal ini tidak sejalan dengan yang dinyatakan oleh Lestari dan Prahmana (2017) bahwa guru tidak diperbolehkan memberikan konsep, sifat, atau jawaban secara langsung pada pembelajaran guided inquiry. Oleh karena itu, pada pembelajaran ini posisi guru seharusnya sebagai fasilitator saja dan hanya 
diperbolehkan untuk membimbing siswa dalam menemukan konsep perbandingan senilai. Untuk lebih jelasnya dapat dlihat pada Gambar 2.

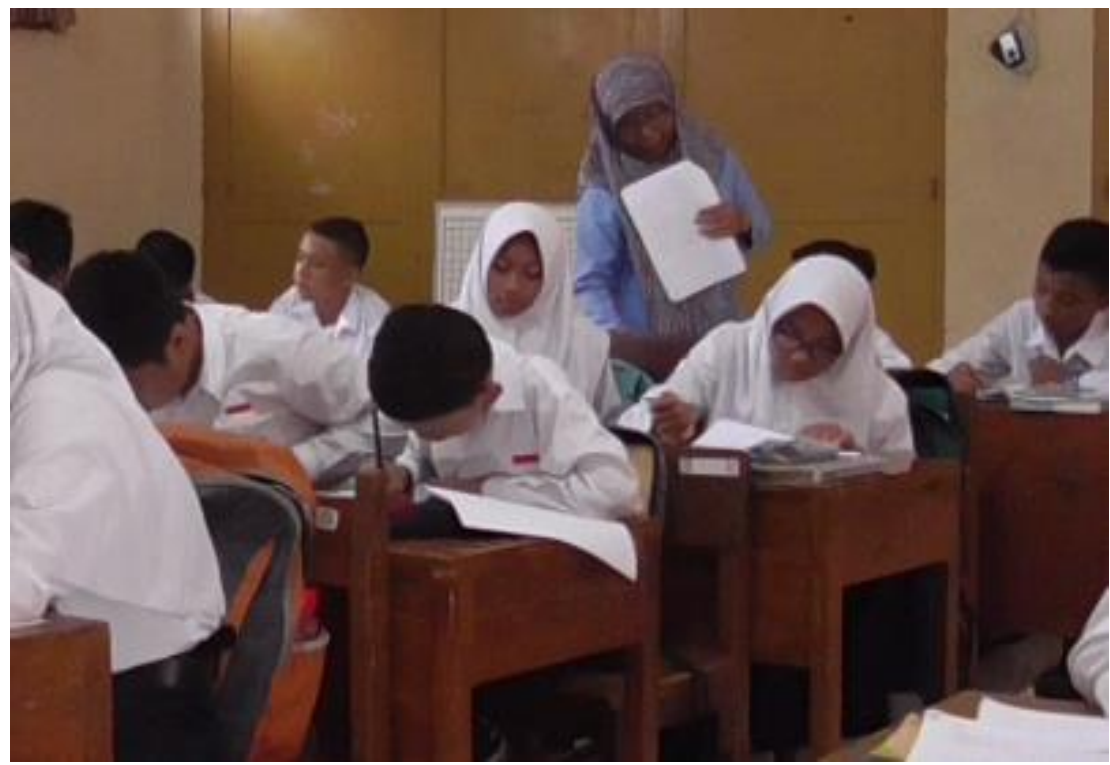

Gambar 2. Guru Membimbing Siswa untuk Menemukan Konsep

Pada pertemuan ketiga, guru memerintahkan siswa untuk membaca dengan teliti perintah dari aktivitas-aktivitas pada LAS. Selanjutnya, guru berkeliling kelas untuk melihat hasil pekerjaan siswa dan membimbing siswa yang mengalami kesulitan. Kesulitan siswa dalam LAS ini yaitu siswa sulit memahami dan belum dapat membuat grafik pada permasalahan perbandingan senilai. Hal ini sesuai dengan pernyataan Husna dan Fatimah (2013) bahwa siswa memiliki keinginan untuk menyelesaikan suatu permasalahan namun tidak mengerti bagaimana cara mengerjakannya, persoalan ini disebut suatu masalah dalam pembelajaran. Pada awalnya hanya dua siswa yang duduk sebangku yang menanyakan masalah grafik tersebut, namun karena siswa yang duduk dibangku depan dan belakang juga antusias untuk memahaminya dan belum memahaminya juga maka guru mencoba membimbing arah pemikiran siswa-siswa tersebut.

Hasil tes tertulis menunjukkan bahwa masih terdapat siswa yang belum dapat menyelesaikan soal-soal tes dengan benar. Kesalahan-kesalahan siswa dalam mengerjakan soal-soal tes tertulis disebabkan oleh kurang teliti dalam menyederhanakan perbandingan, tidak menuliskan model matematika, dan proses perhitungan siswa yang keliru. Kemudian siswa juga tidak mengonversikan besaran waktu agar menjadi satuan 
yang sama. Selain itu, siswa juga tidak mengerjakan secara keseluruhan butir-butir soal higga menyebabkan poin yang diperoleh tidak maksimal.

Data hasil tes tertulis setelah siswa diberikan treatment menunjukkan bahwa ratarata nilai siswa adalah 71,57. Lebih lanjut lagi, frekuensi siswa yang tuntas pada tes tertulis ini adalah sebanyak 18 siswa dengan perolehan nilai tertinggi adalah 93. Nilai terendah yang diperoleh dari seorang siswa adalah 28. Hal ini sejalan dengan penelitian Yanti dan Prahmana (2017) bahwa kelas yang diterapkan dengan model pembelajaran PBL memenuhi rata-rata hasil tes akhir sebesar 76,88 dibandingkan dengan guided inquiry rata-rata hasil tes akhirnya adalah 66,72 . Dari penelitian sebelumnya, dapat kita ambil kesimpulan bahwa hasil rata-rata tes akhir siswa dengan metode pembelajaran guided inquiry yang diterapkan di kelas tidak selalu tinggi.

Berdasarkan hasil penelitian, pembelajaran perbandingan senilai menggunakan LAS dengan model pembelajaran guided inquiry merupakan suatu hal baru bagi siswa sehingga selama kegiatan pembelajaran perbandingan senilai pada pertemuan 1 dan pertemuan 2 siswa masih beradaptasi belajar dengan menggunakan bantuan LAS dan hasil pekerjaan LAS siswa tidak sesuai dengan perintah, sedangkan pada pertemuan ketiga siswa sudah lebih baik dalam memahami LAS yang diberikan sehingga dapat mengerjakannya dengan baik. Hal ini sejalan dengan penelitian sebelumnya yang dilakukan oleh Rahmawati dan Susanti (2016) sehingga memberikan penegasan mengenai implementasi pembelajaran perbandingan senilai melalui model pembelajaran guided inquiry.

\section{SIMPULAN}

Desain pembelajaran materi perbandingan menggunakan metode guided inquiry terdiri dari 3 aktivitas pembelajaran dan 1 aktivitas evaluasi. Guru membimbing siswa untuk menemukan konsep perbandingan senilai melalui aktivitas yang ada dikehidupan sehari-hari menggunakan Lembar Aktivitas Siswa (LAS) berbasis model pembelajaran guided inquiry. Selanjutnya, pada pertemuan pertama dan kedua siswa terlihat masih beradaptasi dengan desain pembelajaran yang diterapkan, namun pada pertemuan berikutnya siswa sudah mulai dapat mengikuti kegiatan pembelajaran dengan lebih baik. Siswa mampu menemukan sisi-sisi yang bersesuaian, mampu menghitung rasio dalam berbagai bentuk, dan mampu menghitung nilai yang ditanyakan dari 
permasalahan kontekstual. Terakhir, hasil belajar siswa setelah melalui serangkaian aktivitas pembelajaran perbandingan senilai yang telah didesain, menunjukkan bahwa rata-rata nilai siswa adalah 71,57. Perolehan nilai tertinggi siswa adalah 93, sedangkan perolehan nilai terendah siswa adalah 28 .

\section{DAFTAR RUJUKAN}

Afandi, A., \& Wustqa, D.U. (2013). Pendekatan open-ended dan inkuiri terbimbing ditinjau dari kemampuan pemecahan masalah dan representasi multipel matematis. Jurnal Pendidikan Matematika, 8(1), 1-11.

Bakker, A. (2004). Design research in statistics education: On symbolizing and computer tools. Doctoral dissertation. Utrecht: Utrecht University.

Diba, F., Zulkardi, \& Saleh, T. (2009). Pengembangan materi pembelajaran bilangan berdasarkan pendidikan matematika realistik untuk siswa Kelas V Sekolah Dasar. Jurnal Pendidikan Matematika, 3(1), 22-46.

Dole, S., Wright, T., Clarke, D., \& Hilton, G. (2009). Proportional Reasoning: Making Connections in Science and Mathematics (MCSAM) (pp. 1-18). Queensland, Australia: The University of Queensland.

Febrian, D. W., Wardono, \& Supriyono. (2013). Pembelajaran TGT melalui pendekatan PMRI berbantuan permainan tradisional terhadap kemampuan berpikir kreatif. Unnes Journal of Mathematics Education, 2(2), 16-24.

Gravemeijer, K., \& Cobb, P. (2006). Design research from a learning design perspective. In Educational design research (pp. 29-63). London: Routledge.

Haeruman, L. D., Rahayu, W., \& Ambarwati, L. (2017). Pengaruh model discovery learning terhadap peningkatan kemampuan berpikir kritis matematis dan selfconfidence ditinjau dari kemampuan awal matematis siswa di Bogor Timur. Jurnal Penelitian Dan Pembelajaran Matematika, 10(2), 157-168.

Husna, M.I., \& Fatimah, S. (2013). Peningkatan kemampuan pemecahan masalah dan komunikasi matematis siswa sekolah menengah pertama melalui model pembelajaran kooperatif tipe Think-Pair-Share (TPS). Jurnal Peluang, 1(2), 8192.

Layn, M.R., \& Kahar, M.S. (2017). Analisis kesalahan siswa dalam menyelesaikan soal cerita matematika. Jurnal Math Educator Nusantara (JMEN), 3(2). 94-102. 
Lestari, R.M., \& Prahmana, R.C.I. (2017). Model guided inquiry, student team achievement division dan kemampuan penalaran matematis siswa. Beta Jurnal Tadris Matematika, 10(2), 153-165.

Machali, I. (2014). Kebijakan perubahan Kurikulum 2013 dalam menyongsong Indonesia Emas Tahun 2045. Jurnal Pendidikan Islam, 3(1), 71-94.

Murpratiwi, G., Nusantara, T., \& Sa'dijah, C. (2019). Analisis kesalahan siswa SMP dalam menyelesaikan soal cerita KPK dan FPB. Prosiding Konferensi Nasional Penelitian Matematika dan Pembelajarannya (KNPMP IV), 1-9.

Novitasari, E., Masykuri, M., \& Aminah, N. S. (2016). Pengembangan modul pembelajaran IPA terpadu berbasis inkuiri terbimbing tema matahari sebagai sumber energi alternatif di kelas VII SMP/MTs. Jurnal Inkuiri, 5(1), 112-121.

Pakarti, H.I., dkk. (2016). Pengaruh pendekatan Realistic Mathematics Education terhadap kemampuan koneksi dan representasi matematis siswa pada materi perbandingan dan skala. Jurnal Pena Ilmiah, 1(1), 571-580.

Permendikbud Nomor 24 Tahun 2016.

Ploom, T. (2013) Educational design research in Ploom $\mathrm{T}$ and Nieveen $\mathrm{N}$ (eds.) Educational Design Research- Part A: An Introduction, Enschede: SLO.

Prahmana, R.C.I. (2017). Design Research. Teori dan Implementasinya: Suatu Pengantar. Depok: PT Raja Grafindo Persada.

Prayitno, A., \& Wulandari, D.T. (2015). Meminimalkan kesalahan konsep pecahan melalui pembelajaran penemuan terbimbing dengan gesture produktif pada siswa SMP. Jurnal Pendidikan Matematika, 1(2), 106-117.

Raharjanti, M., Nusantara, T., \& Mulyati, S. (2016). Kesalahan siswa dalam menyelesaikan permasalahan perbandingan senilai dan berbalik nilai. Prosiding: Konferensi Nasional Penelitian Matematika dan Pembelajarannya (KNPMP I), pp. 312-319.

Rahmasantika, D., \& Prahmana, R.C.I. (2018). Analisis kesalahan siswa pada operasi hitung pecahan berdasarkan tingkat kecerdasan siswa. Journal of Honai Math, 1(2), 81-92.

Rahmawati, S., \& Susanti, E. (2016). Kertas berpetak pada pembelajaran perbandingan senilai. Jurnal Elemen, 2(2), 116-126.

Tanujaya, B., Prahmana R. C. I., \& Mumu, J. (2018). Designing learning activities on 
conditional probability. Journal of Physics: Conference Series, 1088(1), 012087.

Untari, E. (2013). Diagnosis kesulitan belajar pokok bahasan pecahan pada siswa kelas V Sekolah Dasar. Jurnal Ilmiah STKIP PGRI Ngawi. 13(1). 1-8.

Yanti, O.F., \& Prahmana, R.C.I. (2017). Model problem based learning, guided inquiry, dan kemampuan berpikir kritis matematis. Jurnal Review Pembelajaran Matematika, 2(2), 120-130. 